\title{
Geomorphologic and Hydrogeologic Characteristics of Populated Rockslide Deposits (Sagarmatha National Park, Khumbu Himal, Nepal)
}

\author{
Joachim Götz ${ }^{1}$, Johannes Thomas Weidinger ${ }^{1,2}$, Stefan Kraxberger ${ }^{1}$, Anne-Lise Hennecke1, \\ Johannes Buckel1, Basanta Raj Adhikari ${ }^{3}$ \\ ${ }^{1}$ Department of Geography and Geology, University of Salzburg, Salzburg, Austria \\ ${ }^{2}$ Erkudok-Institute, K-Hof-Museums of Gmunden, Gmunden, Austria \\ ${ }^{3}$ Department of Civil Engineering, Tribhuvan University, Kathmandu, Nepal \\ Email: joachim.goetz@sbg.ac.at
}

Received 24 June 2015; accepted 8 September 2015; published 14 September 2015

Copyright (C) 2015 by authors and Scientific Research Publishing Inc.

This work is licensed under the Creative Commons Attribution International License (CC BY). http://creativecommons.org/licenses/by/4.0/

(c) (i) Open Access

\section{Abstract}

Surface morphology and internal composition of large rockslide deposits have been frequently studied, but their hydrogeologic conditions and consequences for (drinking) water quality and quantity on such deposits are largely unknown. In this study we provide first information on this critical relationship for two large rockslide deposits in the Khumbu Himal (Nepal), which are at the same time the main settlement areas in the region. In the first step, we investigated the Lukla and the Namche-Khumjung rockslides with respect to their dimensions and internal composition based on orthophotos and digital elevation models, geomorphologic field mapping, and the analysis of rockslide outcrops. Secondly, we studied their hydrogeologic characteristics by means of spring water mapping, sampling and analyses. As a consequence of the fragmented and highly shattered rockslide material, both deposits are characterized by 1) effective infiltration, 2) short residence times of percolating water and 3) by only small amounts of available spring water and surface runoff at all. Human activity on the studied rockslide deposits can therefore be described as an ambivalent relationship: On the one hand, the rockslide deposits provide a gentle topography and the only available areas for extensive settlements and agriculture in the steep upper DudhKosi catchment; On the other hand, their internal composition accounts for water scarcity-a critical issue for the local population demanding for adaptation strategies, especially in the light of the ever-increasing trekking and expedition tourism in the region.

\section{Keywords}

Khumbu Himal, Geomorphologic and Hydrogeologic Mapping, Rockslide Morphology, Rockslide

How to cite this paper: Götz, J., Weidinger, J.T., Kraxberger, S., Hennecke, A.-L., Buckel, J. and Adhikari, B.R. (2015) Geomorphologic and Hydrogeologic Characteristics of Populated Rockslide Deposits (Sagarmatha National Park, Khumbu Himal, Nepal). Journal of Water Resource and Protection, 7, 1038-1048. http://dx.doi.org/10.4236/jwarp.2015.713085 


\section{Hydrology, Water Scarcity}

\section{Introduction}

Two large "Bergsturz" deposits next to the villages of Lukla and Namche Bazar dominate the landscape in the Khumbu area (Nepal). Based on the pioneering work of Heuberger [1], Heuberger and Weingartner [2] and Heuberger [3], Uhlir [4] showed that at least the Lukla deposits dammeded a huge lake which was filled up with sediments from different source areas through various processes. Later work by Weidinger [5] and Korup and Weidinger [6] suggested these "Bergsturz" events to be rather huge rockslides, with each of them having a volume of $>10^{8} \mathrm{~m}^{3}$ and covering an area of c. $5.5 \mathrm{~km}^{2}$. Even if both events have not yet been dated, their morphology suggests an early postglacial age and huge parts of the initially deposited masses are already excavated by primarily fluvial erosion as indicated by deep gorges underneath both deposits. In recent times, the rockslide deposits represent the largest settlement and agricultural areas [7] of the indigenous Sherpa population in the region and hence agglomeration areas for the ever-increasing expedition and trekking tourism.

Internal structure and composition of huge rockslide deposits is typically characterized by a successively increasing fragmentation of crushed rock down to the rockslide base with occasional evidence of partial melt (frictionite), multiple internal shear planes, and a chaotic boulder carapace on top [8]. These parameters can be observed directly by rockslide outcrops, but also indirectly through the analysis of spring water (temperature, $\mathrm{pH}$, conductivity, chemistry) as demonstrated by Schramm and Weidinger [9]. Settlements located on such deposits might be prone to landslides and debris flows due to a reduced stability of the shattered material, especially in the Himalayas during the annual summer monsoon or as a consequence of earthquakes (e.g. [10]-[12]). Due to its internal composition, rockslide deposits are also supposed to be highly permeable to water suggesting high groundwater flow velocities, and low filtering effects. However, specific hydrogeological conditions of large rockslide deposits and consequences for water quality and quantity have not yet been systematically studied, although such deposits often serve as settlement areas with a gentle topography embedded in steep mountain terrain.

In this study we provide first information on this critical relation for the Lukla and Khumjung-Namche rockslides in the upper Dudh Kosi catchment (Sagarmatha National Park, Solukhumbu, Nepal) based on geomorphologic and hydrogeologic mapping and spring water analyses. We also discuss challenges and consequences with respect to water availability, supply and disposal for the local population living on these deposits. First environmental investigations in this sensitive system were performed by Manfredi et al. [13] and Posch et al. [14] focusing on uncontrolled landfill sites due to growing amounts of garbage from tourists and locals and their impact on water quality. Ghimire et al. [15] analyzed the metal pollution of water bodies in the region and Balestrini et al. [16] studied the chemistry and isotopic composition of precipitation and surface waters in the Khumbu.

\section{Geomorphologic Mapping and Hydrologic Analyses}

Large scale geomorphologic and morphometric analyses of the upper DudhKosi catchment is based on orthophoto interpretation and the analyses of a digital elevation model (DEM, ASTER, $30 \times 30$ m). In April 2015, shortly before the devastating Nepal earthquake, we mapped the two rockslides deposits in the field with respect to geomorphology and hydrogeology using the most detailed available topographic map of the region as base data (1:50.000) [17]. The acquired analogue data on geomorphology (landforms and processes) and hydro (geo) logy (stream, springs, pipes) were afterwards transferred to a digital map using ArcGIS (coordinate system: Nepal Nagarkot TM) with geomorphologic legend symbols referring partly to Kneisel et al. [18] and Otto and Dikau [19].

Eleven springs could be observed within the rockslide deposits during field work which have been mapped, sampled and analyzed. Physical and chemical analyses included the determination of phosphate, nitrate, nitrite, ammonium, pH, conductivity and temperature. These analyses were performed directly in the field using a combined handheld conductivity and pH instrument (Myron L, Techpro II) and a mobile photometer (Söll, Aquacheck). Measured values in the field were validated after field work in the hydrogeological lab using a single- 
beam spectrophotometer (Aqualytic, AL-800, Univ. Salzburg, cooperation S. Hilberg). Spring discharge was assessed by capturing timed flow in a calibrated bucket. To assess the organization of the local supply and disposal of fresh and waste water we additionally interviewed the local population.

\section{The Upper DudhKosi Catchment}

Figure 1 shows a DEM of the upper Dudh Kosi catchment with an area of c.1560 $\mathrm{km}^{2}$ and a tremendous range

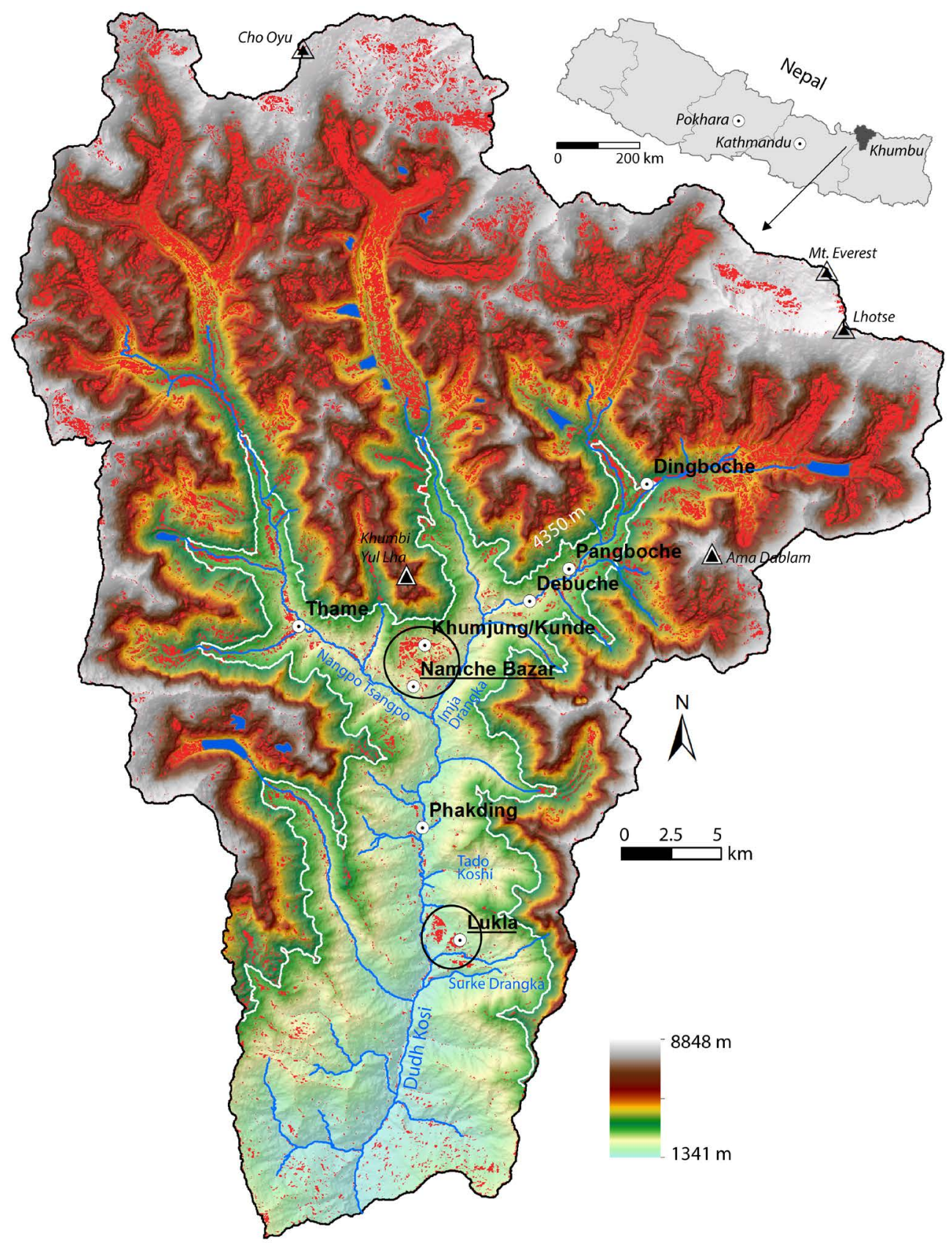

Figure 1. Hillshaded and colored DEM of the upper Dudh Kosi catchment (Aster; $30 \times 30 \mathrm{~m}$ ) including important villages (main centers underlined), the drainage network and lakes (blue), the contour line of 4350 $\mathrm{m}$ (white) indicating the maximum elevation for permanent settlements in the region, and relatively flat areas (slope gradient $<12^{\circ}$; red areas) as preferred settlement locations in the region. Flat areas below 4350 $\mathrm{m}$ largely correspond to the studied Lukla and Namche-Khumjung rockslides (black circles). 
in elevation exceeding $7000 \mathrm{~m}$ between $1341 \mathrm{~m}$ (valley outlet) and $8848 \mathrm{~m}$ (Mt. Everest) within a distance of just c. $50 \mathrm{~km}$. The study area between Lukla and Namche Bazar/Khumjung/Kunde is composed of gneisses, migmatites and granites and located within the tectonic unit of the Higher Himalayan Crystalline [20]. Climatic conditions in the area are characterized by decreasing annual values of temperature and precipitation within the valley towards north. Mean temperature/precipitation in Chaurikarka below Lukla $(2620 \mathrm{~m})$ amounts to $10.4^{\circ} \mathrm{C} / 2034 \mathrm{~mm} \cdot \mathrm{a}^{-1}$; the corresponding values of Namche Bazar $(3450 \mathrm{~m})$ decrease to $6.4^{\circ} \mathrm{C} / 911 \mathrm{~mm} \cdot \mathrm{a}^{-1}$ [21].

Namche and Lukla are the most important economic and touristic centers (trekking, expeditions) in the catchment but smaller permanent settlements and agricultural areas of the local Sherpa population rise up to 4350 $\mathrm{m}$ (Dingboche). Below this altitude gentle terrain is rare and largely restricted to the studied rockslide deposits (Figure 1) where human activity concentrates. Settlements on the deposits include the main centers of Namche and Lukla as well as several smaller villages (Khumjung Kunde, Kenjoma, ..., Syangboche, Chaurikharka, Muse, Senma, Tate, Chheplung, Nachipang; see Figures 1-3). Besides the rockslide deposits, smaller river terraces (e.g. Phakding), truncated debris flow fans from tributaries (e.g. TokTok), and moraines (e.g. Debuche) are populated in the catchment.

\section{The Lukla Rockslide}

The Lukla Rockslide is located in the paragneiss-dominated lithology of the lowest Higher Himalayan Crystalline [22] and was first mentioned by Heuberger and Weingartner [2] as a cluster of individual landslide deposits. Uhlir [4] and Weidinger [5] studied the damming effects of these deposits on the Dudh Kosi River (see below), but until now a detailed geomorphologic map of the area has not been provided. The location of the detachment area and the extent of the deposits remained poorly constrained, so that Owen et al. [23] disputed a mass-movement origin west of Lukla. In Figure 2 we illustrate our interpretations regarding the dimensions of the deposit (affecting both sides of the Dudh Kosi River), the location of the head scarp from Ngotung Ri peak (3473 m) along the $4134 \mathrm{~m}$ until the $4247 \mathrm{~m}$ peaks, and the direction of movement from SW to NE. Typical for large rockslides, Figure 2(a) also illustrates the "Brandung" effect of the rockslide (s) towards east. Moraines and terraces within the Surke Drangka and Handi Khola catchments delineate the rockslide to the south whereas the northern boundary coincides with the Tado Kosi tributary draining into the Dudh Kosi from the east.

Several evidence point to one or several successive giant rockslide (s) in the area ([14], Figure 2(b)) with highly shattered rockslide facies cropping out twice in the northern part of the deposit. The rockslide is also verified by remnants of valley fill deposits adjoining upstream, which accumulated after valley-blocking as already stated by Uhlir [4] and Weidinger [5]. These include (partly varved) lake sediments, fluvial, debris flow and probably also GLOF (glacial lake outburst flood) deposits. The occurrence of frictionite at the rockslide base further indicates a large rockslide [8]. However, neither the age of the rockslide nor the mechanism of movement has been reconstructed so far in detail but the overall topography suggests a polyphase event of advanced age and manifold post-event erosion and accumulation. This is supported by the fact that large parts of the rockslide mass show a terraced morphology with three distinct levels (2500-2550 m, 2650-2750 m, and 2800-2880 m; see Figure 2(a)), which might have developed due to successive rockslide events and/or post-event fluvial erosion. The rockslide terraces are partly covered by a boulder carapace on top, particularly in the proximal areas of the deposit close to the gorge of the DudhKosi River. A succession of debris flow and alluvial deposits on top of the distal parts of the upper rockslide terraces II and III originating from the eastern valley flank also points to extensive and long-term post-event deposition.

The entire landform assemblage is provided in the detailed geomorphologic-hydrogeologic map in Figure 2(b) also showing hydrologic conditions (springs, perennial and periodic streams) and water infrastructure. During fieldwork in April 2015 we observed an overall scarcity of water in the area with only five springs at all supplying relatively small amounts of discharge $(<0.25 \mathrm{l} / \mathrm{s})$. In the rockslide material, infiltration and percolation of water seems to be highly effective as indicated by periodic, short-term spring discharge closely related to rainfall and snowmelt as observed several times in the field. Permanent spring samples provide rather low values of conductivity of $<65 \mu \mathrm{S} / \mathrm{cm}$ also pointing to only short time periods available for mineral solution and high velocities of ground water flow. For the same reason observed values of phosphate $(<0.05 \mathrm{mg} / \mathrm{l})$, nitrate $(<5 \mathrm{mg} / \mathrm{l})$, and nitrite $(<0.03 \mathrm{mg} / \mathrm{l})$ - which were initially acquired as tracers in order to prove the impact of fertilizersmight be around or below the limit of determination. Only ammonium values are somewhat higher $(<0.08 \mathrm{mg} / \mathrm{l})$ pointing to slight anthropogenic or agricultural influence (Table 1). 


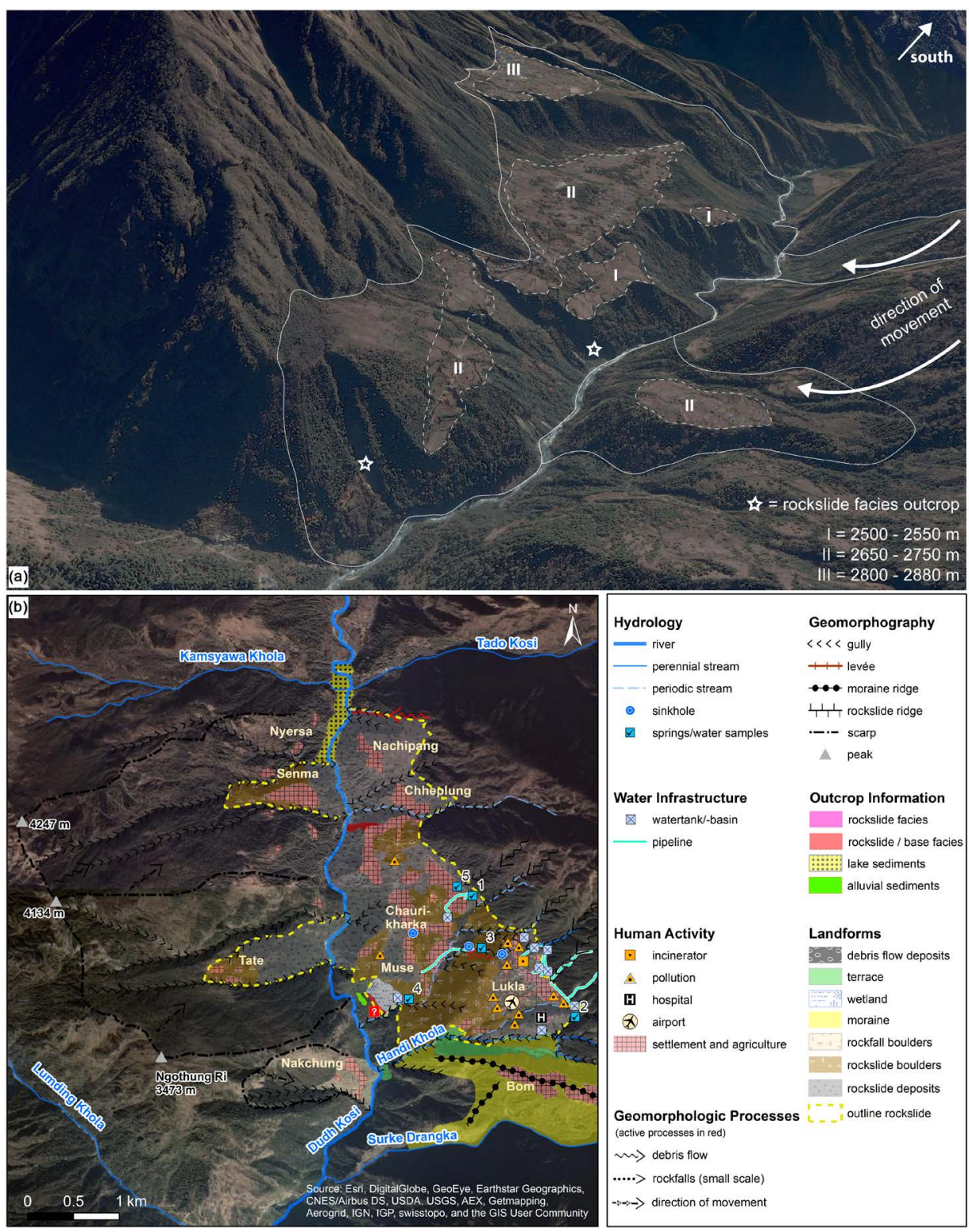

Figure 2. The Lukla Rockslide(s). (a) Google Earth image of the rockslide(s) viewing to southeast indicating the three distinct levels or "rockslide terraces" (I = 2500 - 2550 II = 2650 - 2750 m; III = 2800 - 2880 m); (b) Geomorphologic-hydrogeologic map of the area.

Table 1. Chemical and physical parameters of the rockslides spring water samples. $(*)=$ field analysis.

\begin{tabular}{ccccccccc}
\hline \multicolumn{1}{c}{ The Lukla Rockslide(s) } \\
\hline Spring no. & Discharge $[\mathrm{l} / \mathrm{s}]$ & $\begin{array}{c}\text { Nitrite }[\mathrm{mg} / \mathrm{l}] \\
(* 3.29)\end{array}$ & $\begin{array}{c}\text { Nitrate }[\mathrm{mg} / \mathrm{l}] \\
(* 4.43)\end{array}$ & $\begin{array}{c}\text { Phosphate } \\
{[\mathrm{mg} / \mathrm{l}]}\end{array}$ & $\begin{array}{c}\text { Ammonium } \\
{[\mathrm{mg} / \mathrm{l}]}\end{array}$ & $\mathrm{pH}$ & $\begin{array}{c}\text { Conductivity } \\
{[\mu \mathrm{S} / \mathrm{cm}]}\end{array}$ & $\begin{array}{c}\mathrm{T} \\
{\left[{ }^{\circ} \mathrm{C}\right]}\end{array}$ \\
\hline 1 & c. 0.25 & $<0.0329$ & $<4.43$ & $<0.05$ & 0.03 & 9.5 & 30.8 & 13.3 \\
2 & 0.02 & $<0.0329$ & $<4.43$ & $<0.05$ & 0.08 & 9.1 & 24.7 & 12.7 \\
3 & 0.03 & - & 4.873 & $<0.05$ & - & 6.9 & 43.2 & 12.7 \\
4 & c. 0.20 & - & 4.43 & $<0.05$ & - & 7.4 & 40.8 & 13.7 \\
5 & 0.04 & $<0.0329$ & 4.43 & $<0.05$ & 0.08 & 9.2 & 30.5 & 18.7 \\
\hline
\end{tabular}




\begin{tabular}{cccccccccc}
\hline \multicolumn{7}{c}{ The Namche-Khumjung Rockslide } \\
\hline $7\left(^{*}\right)$ & 0.56 & $<0.0329$ & $<4.43$ & $<0.05$ & $<0.01$ & 6.6 & 33.4 & 11.8 \\
8 & $\mathbf{6 3}$ & $\mathbf{0}$ & $\mathbf{6}$ & $\mathbf{0 . 4 2 2}$ & - & $\mathbf{6 . 2}$ & $\mathbf{1 4 3 . 7}$ & $\mathbf{9 , 5}$ \\
9 & 0.03 & $<0.0329$ & $<4.43$ & $<0.05$ & 0.02 & 8.9 & 17.9 & 12.6 \\
10 & 0.002 & $<0.0329$ & $<4.43$ & $<0.05$ & 0.03 & 7.5 & 33.9 & 13.6 \\
11 & 0.04 & - & 12.404 & 0.3 & - & 7.2 & 89.9 & 11.9 \\
\hline
\end{tabular}

\section{The Khumjung-Namche Rockslide}

A second, probably even larger rockslide deposit in the basin of the Dudh Kosi just c. $20 \mathrm{~km}$ north of Lukla was first mentioned by Heuberger [1] and described in more detail by Heuberger [3]. The rockslide comprises the villages of Namche Bazar, Khumjung and Kunde, which we therefore term Khumjung-Namche Rockslide. North of their confluence, the Nangpo Tsangpo and Imja Drangka Rivers enclose these deposits towards south (Figure 3(a) and Figure 3(b)). The deeply eroded gorges of these rivers suggest 1) enormous rates of postevent incision and 2) that large parts of the deposit have been undermined and excavated. Similar to the Lukla rockslide, the event has not yet been dated even if it might be a major clue for deciphering landscape evolution and quaternary glaciation in the region [24]. Due to the steep, boulder-covered, heavily vegetated, and thus mainly inaccessible terrain only several outcrops of the rockslide's base facies can be detected on the trekking trail towards but below Namche [6]. Along the main trail from Namche to Sanasa rockslide facies crops out frequently suggesting the rockslide's primary sliding surface some $100 \mathrm{~m}$ below.

The rockslide originated from the peak of Khumbi Yul Lha $(5761 \mathrm{~m})$ and it is likely that the masses detached along one of the major fault planes in the scarp area dipping towards south. Since the exact dimensions of the scarp area are difficult to reconstruct we provide a minimum and a maximum model (see Figure 3(b)). The southward motion of the rockslide formed a complex deposit and suggests manifold post-event degradation still active in present times, particularly along a steep erosional front towards the Imja Drangka gorge. Namche Bazar $(3440 \mathrm{~m})$, the main trading and tourist center in the region, is located within this lower level in a "horseshoeshaped" basin (the "Namche amphitheater") eroded back into the rockslide deposits. The area between Namche and the twin-villages of Khumjung and Kunde $(3780 \mathrm{~m})$ is characterized by a carapace of large boulders extending over $400 \mathrm{~m}$ in elevation and up to an altitude of $3900 \mathrm{~m}$. Angular blocks and boulders with diameters of up to $15 \mathrm{~m}$ form here a set of convex, radiating rockslide ridges south of Kunde and Khumjung, and large hummocks between the Syangpoche airstrip and Kunde. Within this boulder carapace, ponor-like sinkholes and dry depressions are frequently observed. To the north, adjoining debris flow and alluvial deposits as well as lake sediments accumulated as a consequence of the damming effect of the rockslide itself. Heuberger [3] already mentioned the striking, poljen-like features filled with alluvial and lacustrine deposits that reach into the rockslide ridges (Figure 3(a) and Figure 3(b)). These post-event deposits provide gentle terrain and huge space for settlements and agriculture. The adjoining hillslopes towards the scarp area are covered by a complex pattern of post-event accumulated landforms, including local moraines, talus slopes (partly indicating former periglacial activity) and small-scale rockfall boulders, dissected by various debris flow channels showing different degrees of recent activity. Figure 3(a) illustrates the rockslide in a panoramic image taken from a local moraine; the detailed geomorphologic-hydrogeologic map is provided in Figure 3(b).

Comparable to the Lukla rockslide the area also lacks water as a consequence of the rockslides material composition facilitating the infiltration and percolation of water. Only six springs with very low discharge $(<0.6 \mathrm{l} / \mathrm{s})$ could be observed on the entire rockslide with similarly low values of conductivity $(<90 \mu \mathrm{S} / \mathrm{cm}$ ), phosphate ( $<0.5 \mathrm{mg} / \mathrm{l}$ ), nitrate $(<13 \mathrm{mg} / \mathrm{l})$, nitrite (below limit of determination), and ammonium ( $<0.04 \mathrm{mg} / \mathrm{l})$ as shown in Table 1. However, with a constant and strong discharge of c. $63 \mathrm{l} / \mathrm{s}$ the most prominent spring is located in the center of Namche (No. 7; Figure 3(b) and Table 1). The catchment of the spring must increase the "horseshoeshaped amphitheater" of Namche by far and suggests a rockslide-internal aquifer system draining huge parts of the mass. We further assume the rockslide base just slightly underneath and the influence of a preserved paleotopography buried by the rockslide but still controlling groundwater flow. 


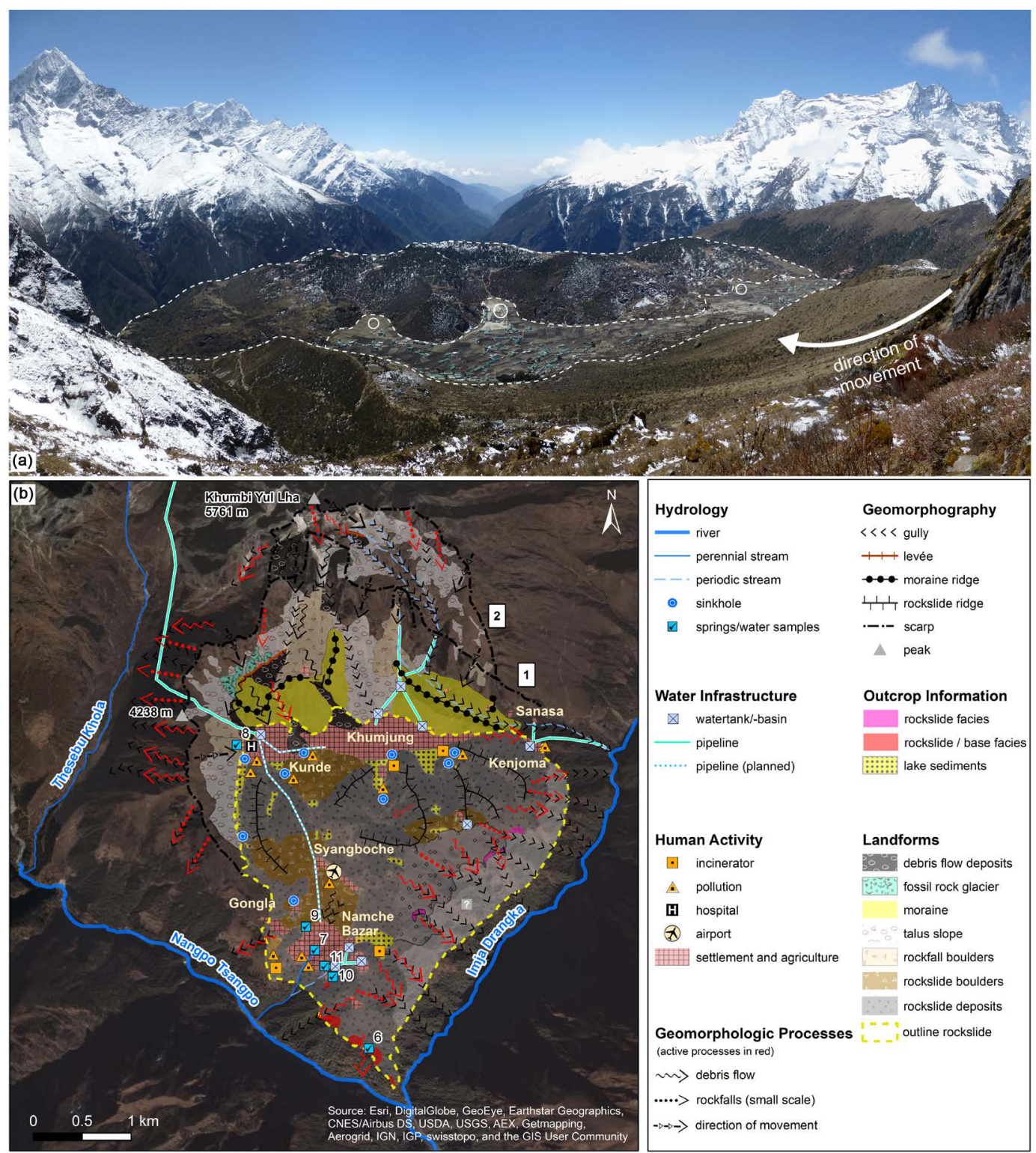

Figure 3. The Khumjung-Namche Rockslide (a): The rockslide seen from above in a panoramic view to south. The populated area on top of damming deposits in front and the rockslide ridges in the back are delineated dashed white; white circles show the "poljen-like" features in the sense of Heuberger [3]; (b): Geomorphologic-hydrogeologic map of the area.

\section{Discussion}

The conceptual model in Figure 4 compiles possible ways of subsurface water flow in a rockslide deposit in dependency of typical grain size and pore volume distribution, sedimentology and internal structures (modified after Weidinger et al. [8]). The model might be useful for applied hydrogeologic studies in other (populated) rockslide areas, particularly in the Himalayas, as it explains the observed water scarcity in general and as it might help to explain and detect potential locations of springs on such deposits. Further populated rockslide deposits in the Himalaya which might be affected by similar hydrologic conditions include e.g. Braga/Manang (Marsyandi/Nepal, see Fort [25], Weidinger [26]), Latamrang (Marsyandi/Nepal, see Korup et al. [27]), ThiniSyang-Jomson (Kali Gandaki/Nepal, see Fort [25]), Kalopani (Kali Gandaki/Nepal, see Weidinger [26]), Dhikur Pokhari (Marsyandi/Nepal, see Korup et al. [27]), Tsergo Ri (Langthang/Nepal, see Weidinger et al. [28]), or Khalsar (Shyok/India, see Weidinger et al. [8]). 


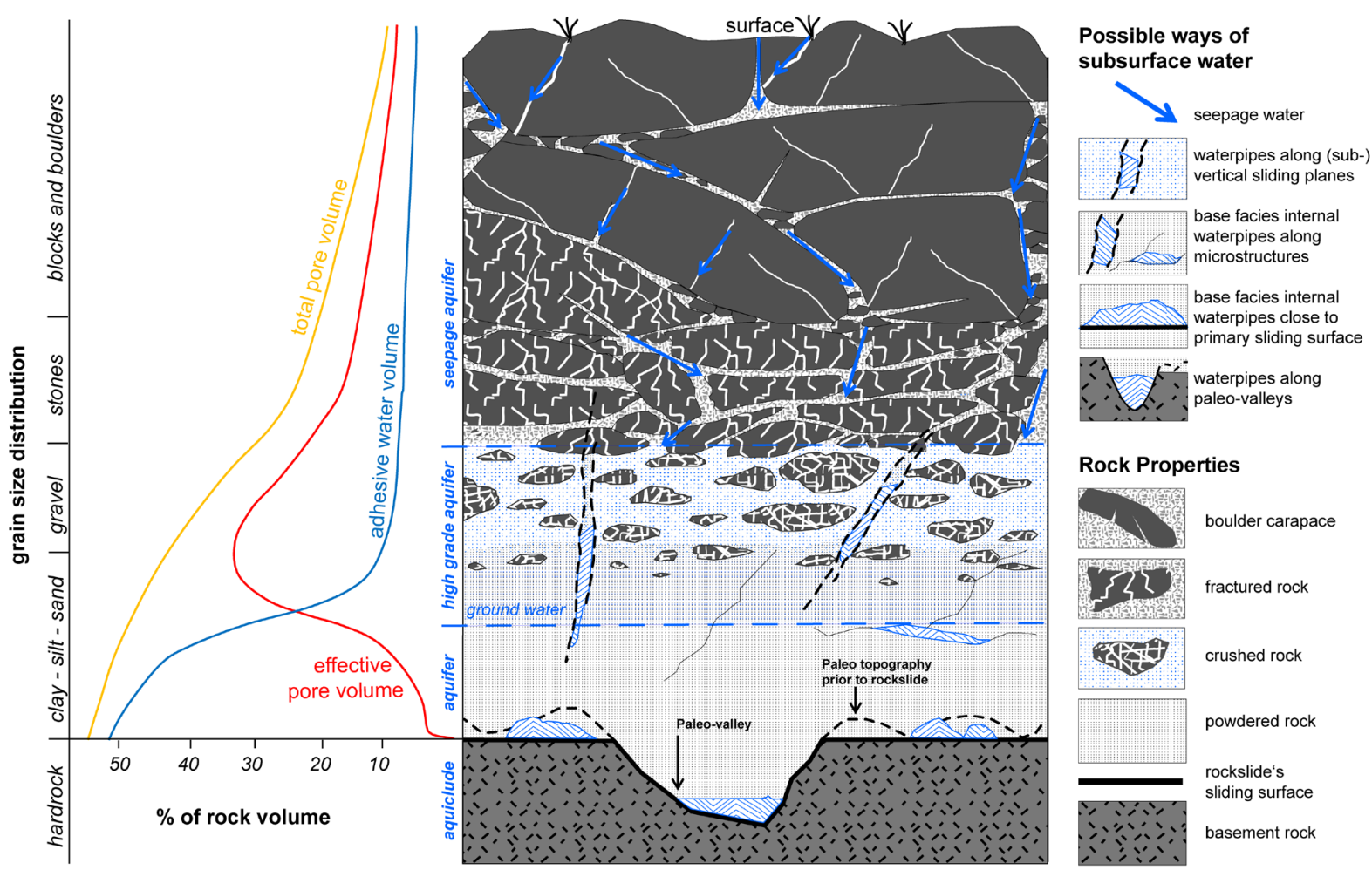

Figure 4. Possible ways of subsurface water in a rockslide deposit in dependency of grain size distribution, total and effective pore volume, sedimentology and internal structures (modified after Weidinger et al. [8]).

The cataclastic rockslide material petro-physically reacts similarly to any other clastic sediment. Thus the effective pore volume $(\mathrm{Ne})$ inside the rockslide to be used by seepage water and ground water flow is determined after Kollmann [29] as:

$$
N e=P-P a \text { and } P=V p / V r
$$

with

$P=$ absolute porosity

$V p=$ volume of pores

$\mathrm{Vr}=$ volume of rock

$\mathrm{Pa}=$ volume of adhesive water

Within those rockslide areas topped by a boulder carapace, infiltration of seepage water is supposed to be most effective. Further down the idealized rockslide profile, the level of rock fragmentation and pore volume grows but decreasing grain sizes suggest a maximum effective pore volume and the most important aquifer within the heavily crushed rocks. In contrast, the deepest powdered (pulverized) section in direct contact to the basement rather retards groundwater flow, due to high compaction and large amounts of immobile cohesive water. The basement rock finally acts as an aquiclude.

However, at least for the Namche-Khumjung Rockslide the observed hydrogeologic characteristics and poljen and ponor-like phenomena highlight a certain similarity to karstic landscapes dominated by subsurface drainage and water scarcity. To better explain several field observations, i.e. the distinct water shortage in the entire area with absent surface drainage, closed but "dry" depressions without signs of water logging due to effective infiltration, sinkholes accelerating infiltration and percolation of water within the rockslide boulders through pipes, and the strong discharge of the Namche spring-we complement the model in Figure 4. Supplementary to the strictly pore volume-based aquifers, water flow inside rockslides might additionally occur along water pipes following internal sliding planes or the basal sliding surface, as well as along microstructures. Furthermore, the paleo or pre-rockslide topography is supposed to influence ground water flow to a certain degree, particularly in the case of the Namche-Khumjung Rockslide. As a possible explanation for the constant and strong discharge of 
the Namche spring we suppose a paleo-valley buried by the rockslide, which still controls a southward oriented subsurface drainage.

Water scarcity and a growing demand of water by tourists and the local population demanded for mitigation and adaptation strategies, and for the implementation of water projects related to the supply and disposal of fresh and waste water in both areas. In 2014 a drinking water project (incl. a fire rescue system) has been completed in Lukla (Lukla water project), initiated and executed by the local population and supported by the Himalayan Trust. In Namche Bazar a drinking water and sewage system was already installed in 2000. The project was driven by local communities with planning support by EcoHimal and the Salzburg AG [30]. Due to ever growing requirements but a limited availability of water on the Khumjung-Namche Rockslide, an ambitious pipeline project is currently in progress connecting to an adjoining glacial catchment in the north. Whereas the supply to Kunde has already been realized, the following sections to Khumjung and further down to Namche (passing through the rockslide ridges) are currently in progress (Figure 3(b)). A local summarized the situation as follows: "There are no dependable permanent water supplies near Namche and Kunde/Khumjung. This is why they're laying pipes to a permanent glacial stream 5 - 6 hours hike away" [31].

\section{Conclusions}

Embedded in steep mountain terrain the Khumjung-Namche and Lukla rockslides (each c. $5.5 \mathrm{~km}^{2}$ ) provide a gentle topography and the most extensive space for settlements and agriculture in the upper Dudh Kosi catchment (Khumbu Himal, Nepal). Consequently, a number of smaller villages and the most important economic and touristic centers of the region (Lukla and Namche Bazar) are located on these deposits.

As observed by geomorphologic and hydrogeologic mapping and spring water sampling and analyses, both rockslides show a general shortage of water, largely missing surface drainage, and an effective ground water flow. Fast infiltration and percolation of water is facilitated by the rockslides internal composition and might occur along various ways, including hollows and pipes between the blocks and boulders, and along microstructures or internal sliding planes within the heavily shattered rockslide material. Groundwater flow along the basal sliding surface might also play a major role for the hydrology of large rockslide deposits, especially if additionally controlled by the pre-event topography, i.e. buried paleo-valleys with concentrated subsurface flow.

Gentle surface characteristics of rockslide deposits thus facilitate human activity, whereas their internal composition often implies a scarcity of water, an ambivalence which might hold true for many populated rockslide deposits, especially in the Himalayas.

\section{Acknowledgements}

We would like to thank Prof S. Hilberg for performing the water analyses at the University of Salzburg, Dr. Christoff Andermann (GFZ Potsdam) for organizational support, and Prof. Oliver Korup (Univ. Potsdam) and an anonymous reviewer for critical comments on the manuscript. Financial support from the Stiftungs-und Förderungsgesellschaft and the open access publication fund of the University of Salzburg are greatly appreciated.

\section{References}

[1] Heuberger, H. (1956) Beobachtungen über die heutige und eiszeitliche Vergletscherung in Ostnepal. Zeitschrift für Gletscherkunde und Glazialgeologie, 3, 349-364.

[2] Heuberger, H. and Weingartner, H. (1985) Die Ausdehnung der letzteiszeitlichen Vergletscherung an der MountEverest-Südflanke, Nepal. Mitteilungen der Österreichischen Geographischen Gesellschaft, 127, 71-80.

[3] Heuberger, H. (1986) Der Bergsturz von Khumdschung, Mount-Everest-Gebiet, Nepal. Material und Technik, 3, 175181.

[4] Uhlir, C.F. (1998) Landslide-Dammed Lakes: A Case Study of the Lamabagar and Chaurikharka Landslide Deposits, Dolakha and Solukhumbu Districts, Eastern Nepal. Journal of the Nepal Geological Society, 18, 329-334.

[5] Weidinger, J.T. (2011) Stability and Life Span of Landslide Dams in the Himalayas (India, Nepal) and the Qin Ling Mountains (China). In: Evans, S.G., Hermanns, R.L., Strom, A. and Scarascia-Mugnozza, G., Eds., Natural and Artificial Rockslide Dams, Springer, Berlin, 243-277. http://dx.doi.org/10.1007/978-3-642-04764-0_8

[6] Korup, O. and Weidinger, J.T. (2011) Rock Type, Precipation, and the Steepness of Himalayan Threshold Hillslopes. Geological Society, 353, 235-249. http://dx.doi.org/10.1144/SP353.12 
[7] Miehe, G. (1991) Die Vegetationskarte des KhumbuHimal (Mt. Everest-Südabdachung) 1:50,000 Gefügemuster der Vegetation und Probleme der Kartierung. Erdkunde, 45, 81-94. http://dx.doi.org/10.3112/erdkunde.1991.02.01

[8] Weidinger, J.T., Korup, O., Munack, H., Altenberger, U., Dunning, S., Tippelt, G. and Lottermoser, W. (2014) Giant Rockslides from the inside. Earth and Planetary Science Letters, 389, 62-73. http://dx.doi.org/10.1016/j.epsl.2013.12.017

[9] Schramm, J.M. and Weidinger, J.T. (1996) Distribution of Electrical Conductivity at TsergoRi Landslide, CentralNorth Nepal. In: Senneset, K., Ed., Proceedings of the 7th International Symposium on Landslides, Balkema, Trondheim, Balkema/Rotterdam/Brookfield, 17-21 June 1996, 889-894.

[10] Dahal, R.K. and Hasegawa, S. (2008) Representative Rainfall Thresholds for Landslides in the Nepal Himalaya. Geomorphology, 100, 429-443. http://dx.doi.org/10.1016/j.geomorph.2008.01.014

[11] Gabet, E.J., Burbank, D.W., Putkonen, J.K., Pratt-Sitaula, B.A. and Ojha, T. (2004) Rainfall Thresholds for Landsliding in the Himalayas of Nepal. Geomorphology, 63, 131-143. http://dx.doi.org/10.1016/j.geomorph.2004.03.011

[12] Petley, D., Hearn, G., Hart, A., Rosser, N., Dunning, S., Oven, K. and Mitchell, W. (2007) Trends in Landslide Occurrence in Nepal. Natural Hazards, 43, 23-44. http://dx.doi.org/10.1007/s11069-006-9100-3

[13] Manfredi, E., Flury, B., Viviano, G., Thakuri, S., Khanal, S.N., Jha, P.K., Maskey, R.K., Kayastha, R.B., Kafle, K.R., Bhochhibhoay, S., Ghimire, N.P., Shrestha, B.B., Chaudhary, G., Giannino, F., Carteni, F., Mazzoleni, S. and Salerno, F. (2010) Solid Waste and Water Quality Management Models for Sagarmatha National Park and Buffer Zone, Nepal. Mountain Research and Development, 30, 127-142. http://dx.doi.org/10.1659/MRD-JOURNAL-D-10-00028.1

[14] Posch, E., Bell, R., Weidinger, J.T. and Glade, T. (2015, submitted) Geomorphic processes, rock quality and solid waste management - Examples from the Mt. Everest Region of Nepal. Journal of Water Resource and Protection.

[15] Ghimire, N.P., Shrestha, B.B., Jha, P.K. and Caravello, G. (2014) Metals Assessments in the Water Bodies of Sagarmatha National Park and Buffer Zone, Nepal. Journal of Water Resource and Protection, 6, 68-74. http://dx.doi.org/10.4236/jwarp.2014.62011

[16] Balestrini, R., Polesello, S. and Sacchi, E. (2014) Chemistry and Isotopic Composition of Precipitation and Surface Waters in Khumbu Valley (Nepal Himalaya): N Dynamics of High Elevation Basins. Science of the Total Environment, 485/486, 681-692. http://dx.doi.org/10.1016/j.scitotenv.2014.03.096

[17] Heuberger, H., Ed. (1987) Shorong-Hinku-Map, 1:50.000 (Third Edition)—Nepal-Kartenwerk der Arbeitsgemeinschaft für vergleichende Hochgebirgsforschung Nr. 5, Nelles Verlag, München.

[18] Kneisel, C., Lehmkuhl, F., Winkler, S., Tressel, E. and Schröder, H. (1998) Legende für geomorphologische Kartierungen im Hochgebirge. Trierer Geographische Studien 18, Geographische Gesellschaft, Trier.

[19] Otto, J.C. and Dikau, R. (2004) Geomorphologic System Analysis of a High Mountain Valley in the Swiss Alps. Zeitschriftfür Geomorphologie, 48, 323-341.

[20] Vuichard, D. (1986) Geological and Petrographical Investigations for the Mountain Hazards Mapping Project, Khumbu Himal, Nepal. Mountain Research and Development, 6, 41-52. http://dx.doi.org/10.2307/3673339

[21] Zimmermann, M., Bichsel, M. and Kienholz, H. (1986) Mountain Hazards in the Khumbu Himal, Nepal, with Prototype Map, Scale 1:50.000. Mountain Research and Development, 6, 29-40. http://dx.doi.org/10.2307/3673338

[22] Vuichard, D. and Zimmermann, M. (1986) The Langmoche Flash Flood, Khumbu Himal, Nepal. Mountain Research and Development, 6, 90-94. http://dx.doi.org/10.2307/3673345

[23] Owen, L.A., Derbyshire, E. and Fort, M. (1998) The Quaternary Glacial History of the Himalaya. Quaternary Proceedings, 6, 91-120.

[24] Götz, J., Weidinger, J.T., Kraxberger, S., Hennecke, A.-L., Buckel, J. and Adhikari, B.R. (In Preparation) Quaternary Landscape Evolution of the DudhKosi Valley.

[25] Fort, M. (2011) Two Large Late Quaternary Rock Slope Failures and Their Geomorphic Significance, Annapurna Himalayas (Nepal). Geografia Fisica e Dinammica Quaternaria, 34, 5-16.

[26] Weidinger, J.T. (2006) Predesign, Failure and Displacement Mechanisms of Large Rockslides in the Annapurna Himalayas, Nepal. Engineering Geology, 83, 201-216. http://dx.doi.org/10.1016/j.enggeo.2005.06.032

[27] Korup, O., Strom, A.L. and Weidinger, J.T. (2006) Fluvial Response to Large Rock-Slope Failures: Examples from the Himalayas, the Tien Shan, and the Southern Alps in New Zealand. Geomorphology, 78, 3-21. http://dx.doi.org/10.1016/j.geomorph.2006.01.020

[28] Weidinger, J.T., Schramm, J.M. and Nuschej, F. (2002) Ore Mineralization Causing Slope Failure in a High-Altitude Mountain Crest-On the Collapse of an 8000m Peak in Nepal. Journal of Asian Earth Sciences, 21, 295-306. http://dx.doi.org/10.1016/S1367-9120(02)00080-9

[29] Kollmann, W. (1986) Die Bestimmung des durchflußwirksamen Porenvolumens von Sedimenten und seine Bedeutung für den Grundwasserschutz. Mitteilungen Österreichische Geologische Gesellschaft, 79, 63-76. 
[30] Gernedel, H. and Hitsch, E. (2001) Drinking Water and Sewage System Namche Bazar. In: Himal, E., Ed., Energy from the Top of the World. Small Hydropower Plant Thame-Namche Bazar, Nepal, Jeewan Printing Support Press, Kathmandu, 40.

[31] Harlin, J. (2014) Everest Alliance Discussions in Nepal during May 2014.

http://www.highmountains.org/blog/everest-alliance-discussions-nepal-during-may-2014 